\title{
Environmental Stressors and Migration: Evidence from Vietnam
}

\author{
VALLY KOUBI $^{\mathrm{a}, \mathrm{b}}$, GABRIELE SPILKER $^{\mathrm{c}}$, LENA SCHAFFER ${ }^{\mathrm{a}}$ and THOMAS BERNAUER ${ }^{\mathrm{a},{ }^{*}}$ \\ ${ }^{\mathrm{a}}$ ETH Zurich, Switzerland \\ ${ }^{\mathrm{b}}$ University of Bern, Switzerland \\ ${ }^{\mathrm{c}}$ University of Salzburg, Austria
}

\begin{abstract}
Summary. - The argument that environmental change is an important driving force of migration has experienced a strong revival in the climate change context. While various studies predict large environmental migration flows due to climate change and other environmental events, the ex post empirical evidence for this phenomenon is inconclusive. We contribute to the extant literature by focusing on the micro-level. We examine whether and how individual perceptions of different types of environmental stressors induce internal migration. The analysis relies on original survey data from Vietnam including both migrants and non-migrants. The results suggest that individual perceptions of long-term environmental events, such as droughts, significantly reduce migration while perceptions of sudden-onset environmental events, such as floods, significantly increase the likelihood of migration controlling for other determinants of migration. These findings also imply that improving the targeting of aid to environmental disaster-affected areas and the financial and technical support for adaptation to environmental change could be the most productive policy-options. Policymakers, thus, need to implement a wide range of developmental policies in combination with environmental ones in order to improve society's ability to effectively cope with environmental change and minimize its effect on migration.
\end{abstract}

Key words — climate change, floods, droughts, migration, micro-level, Vietnam

\section{INTRODUCTION}

The debate on whether and how environmental change impairs human security and ultimately forces people to leave their homes and migrate to places more conducive to their wellbeing has experienced a strong revival in the climate change context. The Intergovernmental Panel on Climate Change (IPCC, 2014a), as well as many academics and policy-makers have argued that climate change is likely to cause mass population dislocations (migration) ${ }^{\mathrm{T}}$ due to extreme weather events, such as stronger and more frequent storms and floods, as well as longer-term, gradual problems, such as droughts and rising sea levels (Foresight Migration \& Global Environmental Change, 2011; Laczko \& Aghazarm, 2009; Myers, 1997, 2002; for a critique, see Kniveton, Schmidt-Verkerk, Smith, \& Black, 2008; see also Gemenne, 2011; Piguet, Pécoud, \& de Guchteneire, 2011, and Piguet, 2010). ${ }^{2}$

A rather large body of the literature examines particular cases of environmental change and seeks to relate observed dislocations of people to observed environmental events or stressors (Doevenspeck, 2011; Dun, 2011; Gray, 2008; Gray \& Mueller, 2012a, 2012b; Halliday, 2006; Henry, Schoumaker, \& Beauchemin, 2004; Jäger, Frühmann, Grünberger, \& Vag, 2009; Massey, Axinn, \& Ghimire, 2010; Mortreux \& Barnett, 2009; Myers, Slack, \& Singelmann, 2008; Nguyen, Raabe, \& Grote, 2015; Robalino, Jimenez, \& Chacon, 2015; Van der Geest, 2011; Warner et al., 2012). ${ }^{3}$

Most of these studies suggest that environmental stressors can induce migration. However, there clearly is room for further research that should address at least two shortcomings of existing work. First, the large majority of studies focuses on one specific country and examines one particular environmental event such as one specific drought or flood and its effects on migration. ${ }^{4}$ Since the effects of an environmental event on migration are likely to be context specific and are mediated by various factors, such as household characteristics, socio-economic and political conditions (e.g., Black et al.,
2011; Hunter et al., 2015), it remains unclear whether effects on migration might differ across different types of environmental stressors in the same country context.

The second limitation is that many studies using micro-level data, usually collected through surveys of individuals or households, concentrate on those persons who have migrated. However, environmental stressors do not affect all people in the same way and individuals do not respond to environmental stressors in a unified, singular manner (e.g., Black et al., 2011; Halliday, 2006; Hunter, 2005; Hunter et al., 2015; Raleigh, 2011). Hence, studies that overlook those who have not migrated are likely to suffer from selection bias because they do not allow for any conclusions with respect to persons who, despite environmental problems, decided not to migrate.

In this paper we contribute to the environmental migration literature by addressing some of the limitations of existing work. We propose a theoretical argument that systematically links individual perceptions of different types of environmental stressors-notably short- vs. long-term environmental events - to decisions of individuals to migrate or stay. We then examine the plausibility of this argument, using original survey data from Vietnam, including both individuals who migrated and individuals who decided to stay. While future climatic change may lead to some international migration and may well be needed, particularly for the citizens of island nations, still we focus on internal migration because there is strong consensus in the scientific literature that most migration flows associated with environmental factors are internal, with the affected individuals/households seeking to find more habitable locations, with better economic opportunities, within their own countries (Adamo \& Izazola, 2010; Hunter et al., 2015; Raleigh et al., 2008).

\footnotetext{
* The authors thank 2 anonymous reviewers for their helpful comments, and Annette Aigner and Dr. Kimberly Howe for excellent research assistance. This paper was supported by funding of the Swiss Network for International Studies (SNIS).
} 
The next section presents the theoretical argument. In the subsequent section we discuss the empirical approach and the results. The final section summarizes the findings and discusses their policy implications.

\section{THEORY}

While migration can be a survival strategy for people experiencing environmental problems, still it is not the only strategy. Reuveny (2007, p. 657), for instance, argues that "people can adapt to environmental problems in three ways: stay in place and do nothing, accepting the costs; stay in place and mitigate the changes; or leave affected areas". Accordingly several authors have argued that environmental conditions are part of a complex pattern of causality (e.g., Black et al., 2011; Hunter et al., 2015; Lonergan, 1998; Suhrke, 1994). They argue that environmental, economic, social, and political factors are interrelated and need to be examined jointly in order to understand the role environmental factors play in population movements. A very useful option for doing so is to draw on the "stress-threshold" model (Wolpert, 1966).

From the perspective of this model, environmental events, for instance floods and droughts, can act as "stressors" that bring about "strains" and motivate individuals to consider migration as a response. ${ }^{5}$ That is, when environmental "stressors" put an individual's wellbeing at risk, decrease her personal income, and/or lower her opportunity for future employment then she is more likely to consider migrating to places with better environmental attributes and better income opportunities. It is worth stressing, however, that environmental events are likely to have asymmetric impacts across the affected population, and hence migration decisions may be affected more by perceptions of environmental problems rather than the environmental event as identified in some objective fashion. ${ }^{6}$ Perspectives on environmental problems are almost by definition relative, influenced by the ability of an individual to cope with and adapt to environmental problems. This ability should be a function of an individual's skills, financial assets, age, gender, and education (Hunter et al., 2015; Piguet et al., 2011). ${ }^{7}$ Environmental stress is, obviously, likely to be more paramount in settings where people are more directly dependent on the natural environment for their livelihood.

However, the presence of environmental stressors will, in most cases, not automatically induce migration (the main exception are major environmental hazards that leave local residents with no choice but to leave). Individuals and societies have adapted to climatic changes over the course of human history (de Menocal, 2001) and existing studies have documented people's resilience to environmental change in several countries of the world such as West African Sahel, Vietnam, and Canadian Arctic (Adger, Kelly, \& Ninh, 2001; Berkes \& Jolly, 2001; Ford, Smit, \& Wandel, 2006; Roncoli, Ingram, \& Kirshen, 2001). It seems, therefore, that individuals are likely to first try and abate the respective environmental problem and/or adapt to it before they consider migration (e.g., Adger, Agrawala, \& Mirza, 2007; Roncoli et al., 2001). The reason is that migration is costly in both financial and sociological/psychological terms because individuals tend to develop strong personal bonds over their lives with their home location and its people (Devine-Wright, 2013; Lewicka, 2011). Consequently, an individual will consider migration only when an environmental event has a major impact on her personal wellbeing and her efforts to adapt to and/or mitigate this impact are failing (Speare, 1974). To what extent this is the case depends on the form and magnitude of the environmental stressor.

The most interesting variation in this respect, in our view, is the difference between sudden vs. slow-onset and short-term vs. long-term events ${ }^{8}$ (see also Foresight Report, 2011; Halliday, 2006; Robalino et al., 2015). Sudden and short-term (rapid) environmental events, such as floods or storms, can have severe impacts - at least in the short run - on the wellbeing of individuals. Affected individuals may move in the aftermath of such natural disasters. ${ }^{9}$ The empirical implication of this argument is that sudden and short-term environmental events have a significant effect on individuals' decision to migrate.

Slow-onset and long-term environmental events, such as droughts, desertification, or sea-level rise are likely to have smaller immediate impacts on the wellbeing of individuals. People can adjust their productive strategies over time when facing such environmental stressors, for example, by investing in irrigation systems, using drought resistant plant and animal varieties, or by diversifying income sources. Moreover, diversification of income sources and a reduction of risk for the household might be accomplished by having a single-family member migrate (Hunter et al., 2015; Stark \& Bloom, 1985). The empirical implication of this argument is that slow-onset and long-term environmental events are less likely to increase the probability of migration.

Overall, we thus expect individuals' reaction to environmental stressors to depend on the nature of the environmental event as it is perceived by the individual. ${ }^{10}$ In the case of sudden and short-term environmental events we expect individuals to migrate (either temporarily or permanently), while we expect no influence of slow-onset and long-term environmental events on migration decisions. The next section presents a systematic analysis of the two hypotheses.

\section{EMPIRICAL ANALYSIS}

Ideally, for a systematic empirical analysis of these hypotheses one needs data for both migrants and non-migrants who originally come from the same area in order to analyze whether environmental stressors influenced migrants' decision to move to another location. Only if one compares individuals who have stayed in the area with those who have left, one is able to isolate the effect of environmental stressors on the decision to migrate since comparing individuals from the same region ensures that the context for all migrants is the same. Unfortunately, no data that meet these requirements exist. The only dataset that comes close to this ideal is the EACHFOR project. ${ }^{11}$ However, the limited number of observations per country case study makes the EACH FOR data difficult to use in a quantitative analysis and thus not very well suited for our purpose.

Consequently, this paper relies on original survey data specifically collected to allow for a quantitative analysis of individual migration choices. In particular, while we sampled households, we ultimately interviewed only one member per household aged 18-64 and asked questions which were related to the particular individual as well as to the household, for example whether a member of the household had already migrated previously. Hence, our approach of analysis while centering on the individual allows us to nevertheless incorporate important household-level factors. The survey was conducted in four districts in four provinces in Vietnam in September and October 2013 and yielded 1,200 completed questionnaires in total of which 600 came from migrants. 
We chose Vietnam as a case study because it provides an ideal testing ground for our theoretical argument. Since our theory postulates different reactions to slow-onset/long-term vs. sudden-onset/short-term environmental events, we ideally need a country in which different parts of the country experience these types of environmental stressors such that one can disentangle the effects from the two types of environmental events on migration choices. Vietnam provides exactly this type of testing ground because over the past $30-50$ years Vietnam has experienced intensified flood, storm, and drought events, water and land salinity, and sea-level rise, with the Mekong and Red River delta regions as well as the North and South Central Coast regions being the most affected (ICEM, 2010; IPCC, 2014b). For instance, in 2013, the year the survey was conducted, the country was affected by 15 typhoons followed by intensive rains, which caused 313 deaths and heavy damages on properties (e.g., 6,401 houses, 17,000 ha of rice and 20,000 ha of vegetables were completely destroyed; over 692,000 houses, 117,000 ha of rice and 154,000 ha of vegetables were flooded and damaged) and infrastructure (e.g., nearly $90 \mathrm{~km}$ of dykes and $894 \mathrm{~km}$ of roads were destroyed) in several provinces. The total value of damage caused by natural disasters in 2013 was estimated to be around 30 trillion dong, twice the 2012 cost (General Statistics Office of Vietnam, 2013). Furthermore, Vietnam is considered to be among the countries with the potential to be the most severely impacted by climate change (MRC, 2009; Dasgupta, Laplante, Meisner, Wheeler, \& Yan, 2009).

We focus on internal migration because of two reasons: First and as discussed above, there is a strong consensus in the existing literature that most migration flows associated with environmental factors are internal (Adamo \& Izazola, 2010). Second, studying internal in contrast to external migration has the advantage that certain factors, which could influence people's decision to migrate but are hard to control for, such as a country's political system, social and or cultural factors, stay constant and therefore cannot influence the decision to migrate. Of course, it is important to keep in mind that our results pertaining to internal migration cannot simply be translated one-to-one to international migration patterns since environmental factors should play a more profound role in the former than in the latter case.

Based on information obtained from the EM-DAT/OFDA/ CRED International Disaster Database and archive research, we first identified four provinces in Vietnam that are mainly characterized by one particular environmental stressor, which can be classified either as slow-onset/long-term or suddenonset/short-term environmental event. Then one district in each of the four provinces was randomly chosen for the location of the survey. In particular, the district of Ba Tri in the province of Ben Tre encounters progressive salinity of its main waterway, the Mekong river, a clear slow-onset and long-term environmental event. The district of Ninh Hai in the province of Ninh Thuan also experiences a long-term environmental event, however, in the form of regular droughts. In contrast, the district of Chau Phu in the province of An Giang due to its history of flooding serves as one of the testing grounds for short-term environmental events. Similarly, the district of Giao Thuy in the province of Nam Dinh also faces shortterm environmental events especially in the form of cyclones. See Table 1 for an overview of the different districts where the survey was conducted.

Within the four districts, three communes were again randomly chosen using a grid system in which the interviews of the non-migrants took place. More precisely, in each of the 12 communes (i.e., three communes in four districts) 50 households were randomly chosen using a grid system with random starting points. Hence 150 non-migrants were interviewed in each of the four districts.

In contrast, random sampling of migrants is hardly possible since by definition they do not live in the same commune anymore. Furthermore, in the locations they have migrated to, they are "hidden" since we cannot know whether a specific person has migrated from the relevant areas. Hence we had to rely on snowballing or chain-referral ${ }^{12}$ to find individuals who came from the exact same locations as the nonmigrants but who now live in the nearest major city (HoChi-Minh-City in the case of the three districts of Ba Tri, Chau Phu, and Ninh Hai, and Hanoi in the case of Giao Thuy). Starting points of the snowballing were obtained by asking the non-migrant interviewees whether they knew of any individuals who had left their commune or district recently and did not belong to the same household. In total, we strived for the same number of migrants to match the non-migrants in each district.

To illustrate the congruence of the migrants' previous location with the non-migrant population, we use GPS coordinates to plot their respective locations on a map of Vietnam (Figure 1). The turquoise color indicates the original locations of the migrants and the blue the places in which the non-migrants live. The map clearly shows the high congruence of the two types of locations providing strong confidence that the original locations of the migrants - and along with it the environmental factorswere identical to those of the non-migrants.

Despite this congruence between migrants and non-migrants given their previous location, it is important to keep in mind what this sampling procedure implies for the interpretation of our results. First of all, we sampled regions in Vietnam that were more prone than others to having experienced environmental events and thus all individuals, whether migrants or not, are more likely to have experienced environmental changes. Hence our results make finding environmentally induced migration patterns most likely. Second, within these regions only the non-migrants were sampled randomly but the migrants were sampled using snow-balling. This could induce some bias if identifying the migrants was somehow related to them having experienced specific patterns of environmental events that are different from the non-migrants. However, since we simply asked for anyone who has migrated and since villages/communes are relatively small and thus individuals will most likely know of anyone who migrated, this should not be the case.

Finally, all interviews were personal interviews consisting of both closed and open-ended questions lasting for about

Table 1. Sampling procedure

\begin{tabular}{|c|c|c|c|c|}
\hline Province & District & Reason for selection & Non-migrants & Migrants \\
\hline Ben Tre & $\mathrm{Ba}$ Tri & Progressive salinity of water & 150 & 150 in Ho-Chi-Minh-City \\
\hline An Giang & Chau Puh & Regular floods & 150 & 150 in Ho-Chi-Minh-City \\
\hline Ninh Thuan & Ninh Hai & Regular droughts & 150 & 150 in Ho-Chi-Minh-City \\
\hline Nam Dinh & Giao Thuy & Regular storms; Tropical cyclone Bebinca in June 2013 & 150 & 150 in Hanoi \\
\hline
\end{tabular}




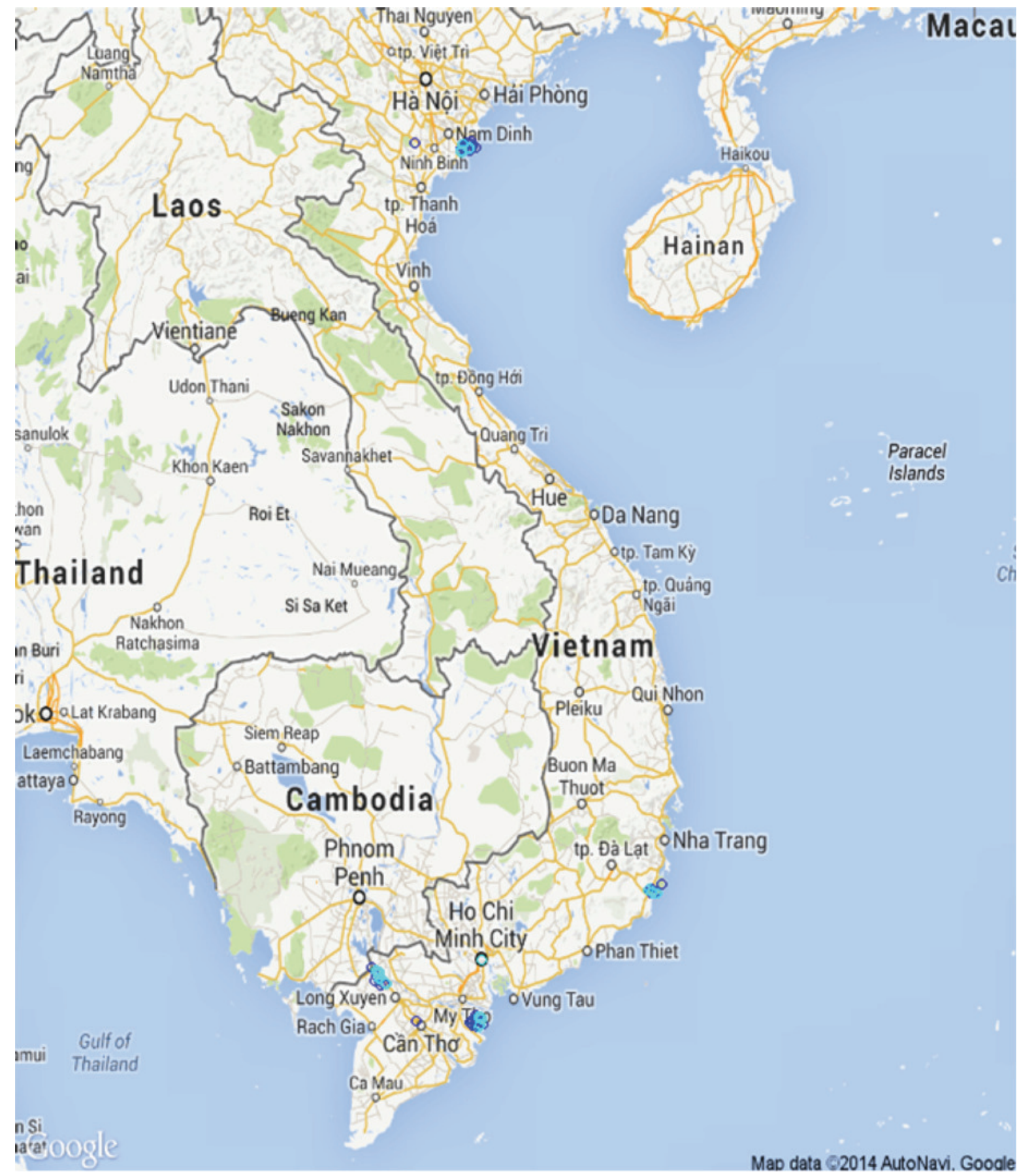

Figure 1. Locations of non-migrants and migrants.

30 min. We asked all individuals about their experience with the latest environmental event as well as certain important personal information such as age, profession, or education levels. Those parts of the two questionnaires that are relevant to this study can be found in the Appendix.

\section{(a) Operationalization of variables}

Our dependent variable measures a person's decision to migrate. It takes on the value 1 for those individuals who migrated and the value 0 for those who did not.
For our two main independent variables covering environmental stressors, sudden and short-term environmental versus slow-onset and long-term environmental events, we relied on a question asking respondents to describe the main weather event(s) they had experienced during the past 5 years. Both migrants and non-migrants answered this particular question. Respondents could not only choose between several weather events such as heavy rain/storm/flood or drought/desertifica tion/salinity but could also list any other weather event that was not listed or were able to state that no weather events have occurred lately. If individuals mentioned that they experienced 
heavy rain, flood, hail, storm, cyclone, typhoon, and/or landslide/mudslide, we coded this due to the short-term nature of the event as sudden and short-term environmental stressor. In contrast, we coded any mentioning of salinity, drought, or desertification as slow-onset and long-term environmental stressor. Due to their long-term nature, we expect these latter environmental events to lead to more adaption and thus to a lower likelihood of migration while we expect the short-term environmental events to lead to an increased likelihood of migration.

In addition, we incorporate several control variables in our model that are typical in the study of individual-level migration choices. Information for all of the variables comes from the survey. First, we include a respondent's gender and age since women as well as older individuals are less likely to migrate all else equal. Following recent explanatory models of migration networks, we include a dummy variable capturing whether another family member has migrated. These models emphasize that migration decisions are taken in a broader socio-economic context. Such networks by sharply reducing the costs and risks associated with migration increase the likelihood that relatives and friends will follow once the first migrant has settled in her/ his destination (Massey, 1990; Massey et al., 1993).

Furthermore to control whether economic problems drove the migrants' decision rather than environmental stressors, we rely on four different proxy variables based on four different questions from our survey, which we use in the four different models displayed below. First, we rely on respondents' selfassessment as to whether economic reasons influenced their decision to migrate or not. In particular, all migrants were asked about their reasons to migrate and they could choose between many categories (e.g., social, political, environmental, or economic reasons). For all respondents who stated that economic reasons contributed to their decision to migrate, we coded the variable "economic reason" as 1 and for all other respondents as 0 . Since we could not ask the non-migrants the same question, we asked them whether they have ever thought about migrating from their location and if so, which were the reasons for doing so. For those respondents who stated that they thought about migrating because of economic reasons, the variable "economic reason" takes the value of 1 and for all other respondents 0 . However, since this self-assessment might be problematic as individuals might want to over- or understate the relevance of certain factors due to personal reasons (e.g., non-migrants might not want to admit that economically they are not doing well), we use three other variables as additional proxies for the economic reasons of migration.

As the second proxy, we rely on the interviewers' classification of the respondent's economic household status. In particular, interviewers, based on a predetermined household status scale, classified whether a household is economically below average, average, or above average. We include two dummy variables - below and above average - in our second model below while those individuals with average economic status serve as the baseline category. Third, we rely on a respondent's profession to proxy his source of income, which should be related to the household's economic wellbeing. We include the following five professions in our model while individuals working in agriculture sector serve as the baseline category: civil servants, individuals living from business sales, workers (industry, handicrafts etc.), individuals with elementary professions such as day labor, and individuals living from remittances or other sources of income. As our final variable to control for the economic reasons of migration, we include a respondent's level of education. In particular, we include three dummy variables: whether a respondent has no formal education, whether a respondent received at maximum primary education, or whether a respondent received at maximum secondary education. Those individuals with higher education levels serve as the baseline category. Table 2 shows the descriptive statistics.

\section{(b) Results}

Since our dependent variable is binary we use logistic regression models to analyze how environmental variables relate to a respondent's decision to migrate. We cluster the standard errors by district to control for the fact that individuals from the same district might show more similar response patterns than individuals from different districts. Table 3 shows the results of seven logistic regression models proceeding in a stepwise order. Model 1 shows the results if we incorporate

Table 2. Descriptive statistics

\begin{tabular}{|c|c|c|c|}
\hline Variable & Yes & No & $\mathrm{N}$ \\
\hline Migrants & 600 & 600 & 1,200 \\
\hline Sudden events & 982 & 218 & 1,200 \\
\hline Gradual events & 352 & 848 & 1,200 \\
\hline Female & 685 & 515 & 1,200 \\
\hline Family member has migrated & 459 & 739 & 1,198 \\
\hline Household below average & 300 & 479 & 779 \\
\hline Household above average & 153 & 626 & 779 \\
\hline Economic reason & 565 & 635 & 1,200 \\
\hline Farmers & 618 & 582 & 1,200 \\
\hline Civil servants & 63 & 1,137 & 1,200 \\
\hline Business sales & 237 & 963 & 1,200 \\
\hline Workers & 125 & 1,075 & 1,200 \\
\hline Elementary occupation & 151 & 1,049 & 1,200 \\
\hline Remittances & 6 & 1,194 & 1,200 \\
\hline No education & 21 & 1,179 & 1,200 \\
\hline Primary education & 232 & 968 & 1,200 \\
\hline Secondary education & 642 & 558 & 1,200 \\
\hline Higher education & 303 & 897 & 1,200 \\
\hline \multirow[t]{2}{*}{ Age } & Min: 18 & Mean: 34 & 1,200 \\
\hline & Max: 64 & Std. Dev. 12.04 & \\
\hline
\end{tabular}


Table 3. Baseline logistic models

\begin{tabular}{|c|c|c|c|c|c|c|c|}
\hline & (1) & (2) & (3) & (4) & (5) & (6) & (7) \\
\hline Sudden events & $\begin{array}{l}2.28^{* * *} \\
(0.633)\end{array}$ & $\begin{array}{l}2.06^{* * *} \\
(0.698)\end{array}$ & $\begin{array}{l}1.67^{* * *} \\
(0.229)\end{array}$ & $\begin{array}{l}2.29^{* * *} \\
(0.794)\end{array}$ & $\begin{array}{l}1.89^{* * *} \\
(0.637)\end{array}$ & $\begin{array}{l}2.17^{* * *} \\
(0.714)\end{array}$ & $\begin{array}{l}1.15^{* * *} \\
(0.403)\end{array}$ \\
\hline Gradual events & $\begin{array}{c}-0.69^{* * *} \\
(0.177)\end{array}$ & $\begin{array}{c}-0.88^{* * *} \\
(0.183)\end{array}$ & $\begin{array}{l}-0.63 \\
(0.528)\end{array}$ & $\begin{array}{l}-0.55 \\
(0.463)\end{array}$ & $\begin{array}{c}-0.92^{* * * *} \\
(0.162)\end{array}$ & $\begin{array}{c}-0.95^{* * *} \\
(0.172)\end{array}$ & $\begin{array}{l}-0.76 \\
(0.598)\end{array}$ \\
\hline Female & & $\begin{array}{c}-0.48^{* * *} \\
(0.178)\end{array}$ & $\begin{array}{l}-0.30 \\
(0.382)\end{array}$ & $\begin{array}{l}-0.19 \\
(0.228)\end{array}$ & $\begin{array}{c}-0.35 \\
(0.225)\end{array}$ & $\begin{array}{c}-0.45^{* * *} \\
(0.170)\end{array}$ & $\begin{array}{l}-0.20 \\
(0.544)\end{array}$ \\
\hline Age & & $\begin{array}{c}-0.12^{* * *} \\
(0.015)\end{array}$ & $\begin{array}{c}-0.16^{* * *} \\
(0.019)\end{array}$ & $\begin{array}{c}-0.09^{* * *} \\
(0.016)\end{array}$ & $\begin{array}{c}-0.10^{* * *} \\
(0.010)\end{array}$ & $\begin{array}{c}-0.13^{* * *} \\
(0.012)\end{array}$ & $\begin{array}{c}-0.08^{* * *} \\
(0.010)\end{array}$ \\
\hline Family member has migrated & & $\begin{array}{c}0.62 \\
(0.659)\end{array}$ & $\begin{array}{c}0.96^{*} \\
(0.545)\end{array}$ & $\begin{array}{c}0.80 \\
(0.857)\end{array}$ & $\begin{array}{c}0.50 \\
(0.720)\end{array}$ & $\begin{array}{c}0.72 \\
(0.649)\end{array}$ & $\begin{array}{c}1.12 \\
(1.118)\end{array}$ \\
\hline Economic reason & & & $\begin{array}{l}7.12^{* * *} \\
(0.869)\end{array}$ & & & & $\begin{array}{l}7.17^{* * *} \\
(0.777)\end{array}$ \\
\hline Household below average & & & & $\begin{array}{c}-0.68 \\
(0.568)\end{array}$ & & & $\begin{array}{c}-1.48^{* * *} \\
(0.238)\end{array}$ \\
\hline Household above average & & & & $\begin{array}{c}0.12 \\
(0.116)\end{array}$ & & & $\begin{array}{l}-1.21 \\
(1.017)\end{array}$ \\
\hline No education & & & & & $\begin{array}{c}-1.78^{* *} \\
(0.706)\end{array}$ & & $\begin{array}{c}-2.58^{* * * *} \\
(0.755)\end{array}$ \\
\hline Primary education & & & & & $\begin{array}{c}-2.52^{* * *} \\
(0.927)\end{array}$ & & $\begin{array}{c}-3.86^{* * *} \\
(0.955)\end{array}$ \\
\hline Secondary education & & & & & $\begin{array}{c}-1.44^{* * *} \\
(0.379)\end{array}$ & & $\begin{array}{c}-2.83^{* * *} \\
(0.555)\end{array}$ \\
\hline Civil servants & & & & & & $\begin{array}{c}-0.40 \\
(0.290)\end{array}$ & $\begin{array}{l}-0.39 \\
(0.687)\end{array}$ \\
\hline Business Sales & & & & & & $\begin{array}{c}-0.52 \\
(0.372)\end{array}$ & $\begin{array}{l}-0.52 \\
(0.334)\end{array}$ \\
\hline Workers & & & & & & $\begin{array}{c}-1.88^{* * * *} \\
(0.303)\end{array}$ & $\begin{array}{l}-0.29 \\
(0.724)\end{array}$ \\
\hline Elementary occupation & & & & & & $\begin{array}{c}-1.43^{* * *} \\
(0.447)\end{array}$ & $\begin{array}{c}-2.21^{* * *} \\
(0.546)\end{array}$ \\
\hline Remittances & & & & & & $\begin{array}{c}-2.14 \\
(1.626)\end{array}$ & \\
\hline Constant & $\begin{array}{c}-1.76^{* * *} \\
(0.365)\end{array}$ & $\begin{array}{l}2.58^{* * *} \\
(0.308)\end{array}$ & $\begin{array}{c}1.05^{* *} \\
(0.485)\end{array}$ & $\begin{array}{c}0.15 \\
(0.623)\end{array}$ & $\begin{array}{l}3.21^{* * *} \\
(0.325)\end{array}$ & $\begin{array}{l}3.12^{* * * *} \\
(0.365)\end{array}$ & $\begin{array}{c}1.41 \\
(1.218)\end{array}$ \\
\hline Pseudo $R^{2}$ & 0.12 & 0.34 & 0.82 & 0.25 & 0.39 & 0.38 & 0.79 \\
\hline Log like. & -731.74 & -550.83 & -146.76 & -315.11 & -505.89 & -512.73 & -85.25 \\
\hline Observations & 1,200 & 1,198 & 1,198 & 778 & 1,198 & 1,198 & 773 \\
\hline
\end{tabular}

Robust standard errors in parentheses clustered by district; ${ }^{*} p<0.10,{ }^{* *} p<0.05,{ }^{* * *} p<0.01$.

only the environmental variables. Model 2 shows the results with control variables except for any of the proxies of economic reasons of migration. Models 3-6 use in addition one of the four economic reasons proxies and Model 7, finally, shows the results using all independent variables together.

In all models and in line with our theoretical argument, we find that sudden and short-term environmental weather events such as floods or typhoons significantly increase the likelihood that an individual opts for migration. This finding supports the idea that short-term environmental events have severe impacts on the wellbeing of individuals and affected individuals therefore migrate to other regions. In contrast, slow-onset and long-term environmental events do either not influenceif we incorporate the economic self-assessment or the assessment of the household status in the model-or significantly reduce the likelihood of migration. The finding is consistent with the argument set forth in the previous section of the paper, where we claim that people are unlikely to migrate in response to longer-term environmental stressors, such as droughts and water/land salinity, due to their close bonds with the location and therefore adaptation and mitigation should be the preferred options. While this result corroborates Dun's (2011) conclusion that people prefer to stay living along the Mekong River rather than to relocate despite the severe erosion of the river banks, it is not aligned with much of the existing empirical literature which reports that droughts and aridity increase migration (Foresight, 2011; Warner et al., 2012). Hence, we observe that environmental events can indeed act as stressors that motivate individuals to migrate. However, this only happens if individuals are faced with short-term environmental stressors.

Concerning the control variables (Model 2), similarly to other studies (e.g., Jäger et al., 2009; Warner et al., 2012), we find that female respondents and older respondents are less likely to migrate although the gender variable does not reach standard significance levels in most models. In contrast, if a family member has already migrated the average survey respondent is more likely to opt for migration, too. However, this effect is only significantly different from zero in Model 3, in which we use the economic self-assessment variable. This finding thus offers only limited support for the network perspective on migration.

Interestingly, concerning a respondent's economic status, it depends on the proxy used whether we see any effects. If we rely on the respondents' self-assessment to measure the economic reasons for migration, we do observe that economic 
reasons significantly increase the de facto decision to migrate (Model 3). In contrast, as shown in Model 4, the more objective classification of households into below average, average, and above average households does not significantly relate to the likelihood of migration. Model 5 shows that education strongly matters for individuals' decision to migrate. Relative to those individuals with a higher level of education, which serve as the baseline category in our model, individuals with lower levels of education are less likely to opt for migration. In light of potential opportunity costs, this finding suggests that well-educated individuals could be more likely to opt for migration since their education level should allow them to more easily find employment at a new location. And finally as displayed in Model 6, relative to agricultural workers who serve as the baseline category, all other professions have a lower likelihood of migration.

Since it is difficult to interpret the exact effect size in a logistic model, Figures 2 and 3 provide an illustration of what the results mean for our two main independent variables. Based on Model 3 and Model 5 respectively, we simulated predicted probabilities for the two environmental events following King, Tomz, and Wittenberg (2000). More precisely, Figure 2 shows the first difference estimates for the variables measuring sudden-onset as well as slow-onset environmental stressors based on the model that measures economic wellbeing with the self-assessment variable. Figure 3 shows the first difference

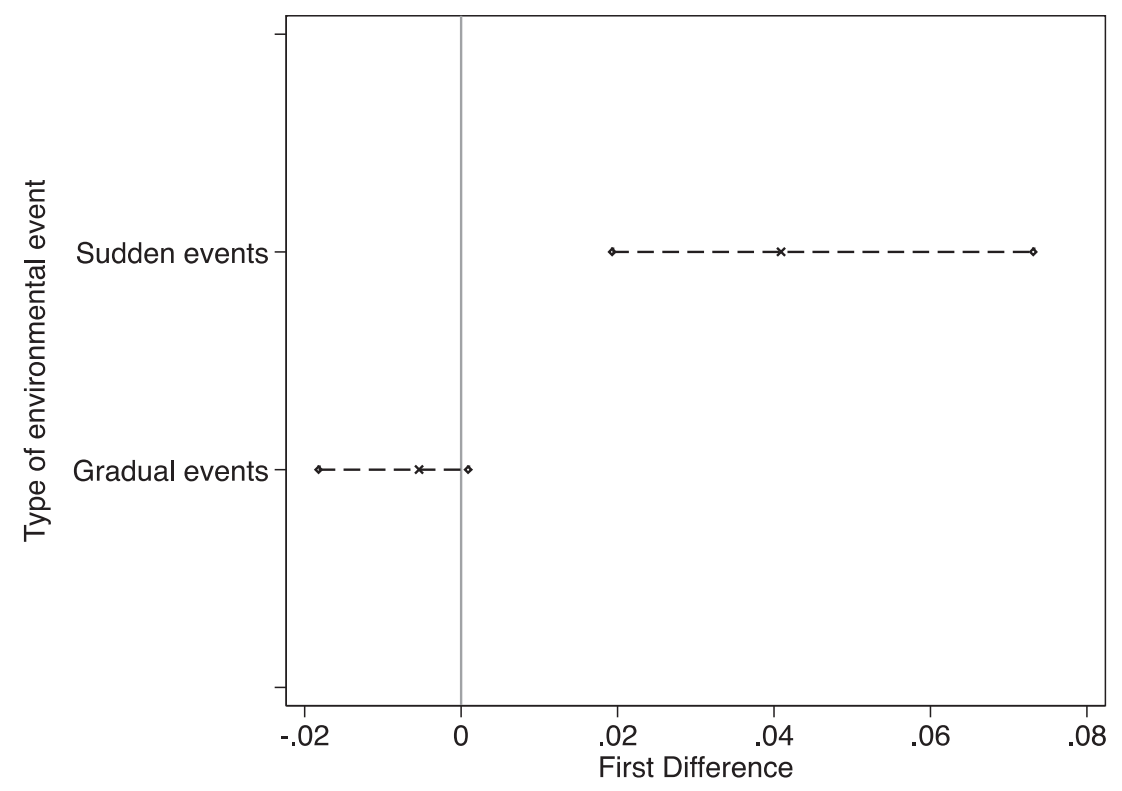

Figure 2. First-difference estimates calculated based on economic reason Model 3 in Table 3 using simulated parameter values (King et al., 2000). Estimate of first difference represented by $\times$. Dashed lines signify $95 \%$ confidence interval. Solid line marks 0-threshold.

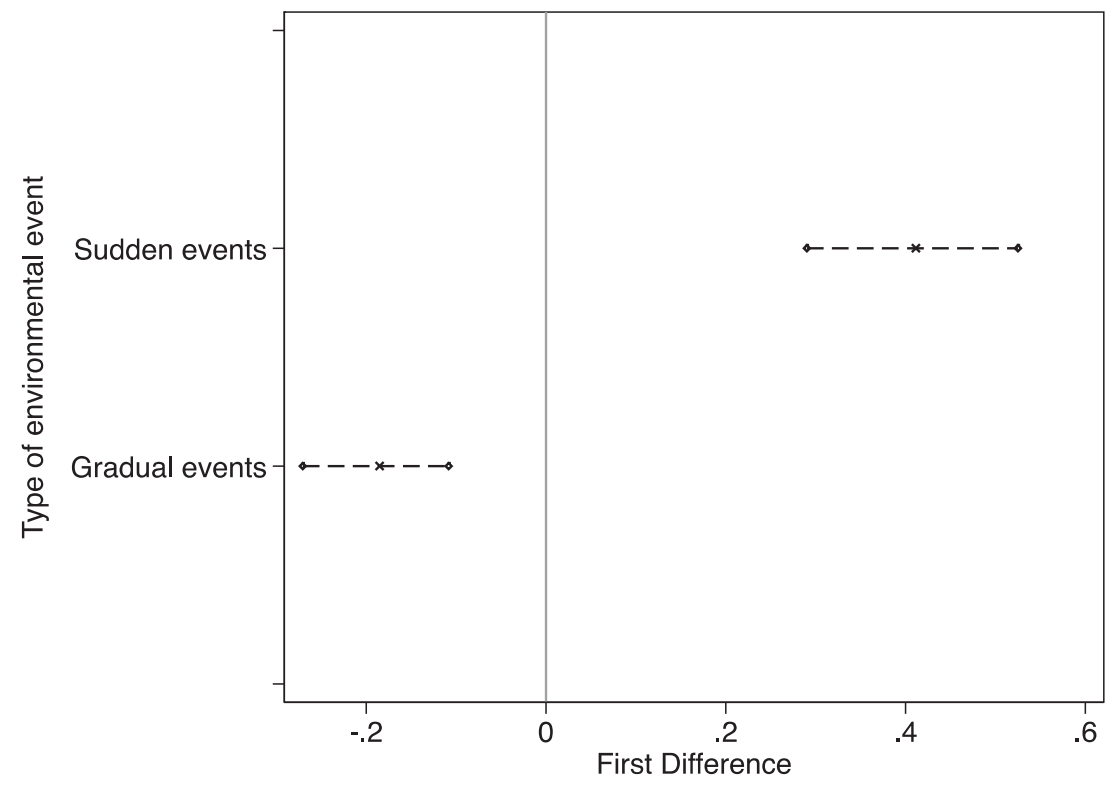

Figure 3. First-difference estimates calculated based on education (Model 5 ) in Table 3 using simulated parameter values (King et al., 2000). Estimate of first difference represented by $\times$. Dashed lines signify 95\% confidence interval. Solid line marks 0-threshold. 
estimates based on the model with the three education dummies. The dashed lines always signify $95 \%$ confidence intervals and the solid line marks the zero-threshold.

Figure 2 clearly shows that the presence of gradual environmental events does not significantly affect the likelihood of migration since the first difference crosses the zero-threshold. In contrast, the presence of sudden-onset environmental events increases the likelihood of migration by four percentage points. This does not look like a major effect, which is, however, mostly due to the overwhelming effect of the economic reason variable, which crowds out any other effects. This can be seen in relation to Figure 3, which shows the same picture but is based on our estimates on the model with the education variables. In this case, we observe a difference in the likelihood of migration of about 40 percentage points if a sudden environmental event is present. In contrast, the likelihood of migration decreases by about 18 percentage points if gradual environmental events take place. These effects are by far larger than those displayed in Figure 2, which highlights the importance of controlling for other migration-related factors. Hence the exact size of the environmental variables is greatly dependent on model specification. While we always observe a significantly higher likelihood of migration in the presence of sudden-onset events, we estimate the size of this impact to be rather small if we include a respondent's selfassessment of the economic reasons that led to migration or rather large if we include her level of education instead. Since the economic self-assessment model might understate while the education model might overstate the effect because the first is probably giving too much weight to economic concerns and the second too little, the "real" effect size most likely is somewhere in between.

In summary, our results indicate that it is important to consider the specific context in which environmental stressors could, in principle, influence decisions to migrate. They show that environmental events do not necessarily force people to migrate. The prevailing option, when facing long-term environmental stress, is adaptation. Only when people are confronted with sudden-onset and short-term environmental events such as floods they are willing to accept the costs of migration.

\section{CONCLUSION}

Does environmental change cause migration? While research on the environment-migration nexus has been conducted for some time, the issue has become highly salient in the context of the climate change debate. We contribute to the existing literature by developing a theoretical argument that considers individual perceptions of different types of environmental stressors and their likely effects on individuals' choice to migrate or stay. Empirically, our research adds to the existing literature in at least two ways: we differentiate between two types of environmental stressors by considering both sudden-onset and long-term environmental events and use original micro-level survey data from Vietnam for persons who migrated and for those who decided to stay.
The results suggest that sudden-onset environmental events, such as floods or typhoons, increase the likelihood that individuals opt to move whereas longer-term environmental problems, such as droughts or salinity, reduce the likelihood of migration. This result suggests that individuals might respond to long-term environmental events with adaptation, rather than migration, indicating that individuals are socially and economically bonded to their location.

The obvious limitations of our study are that it focuses mainly on micro-level factors and on one country, namely Vietnam, while existing theoretical research reveals that migration decisions are shaped by environmental events combined with micro-level (individual), meso-level (household) and macro-level (historical, economic, and political) contextual factors (Black et al., 2011, p. 5; Hunter et al., 2015, p. 6). Extant empirical research-mainly at the household levelalso shows that migration is part of a broader household livelihood strategy to diversify income and secure livelihoods in the face of deteriorating environmental conditions independently of the type of the environmental event in the place of origin (e.g., Foresight, 2011; Warner et al., 2012). That said, we view our contribution primarily as a conceptual and theoretical contribution at the micro-level, complemented by an empirical case study of migration patterns in Vietnam that is characterized by a rigorous empirical design combined with original and highly reliable data. While these limitations still allow for some meaningful insights, as shown in this paper, further research will have to focus on larger-scale primary data collection to compare several different countries. Furthermore, future research into the temporal dimension is also needed to determine the "threshold" by which environmental migration sets in when facing long-term degradation and which micro-level, meso-level, and macro-level factors may best support and complement individual mitigation and adaptation strategies.

These data limitations notwithstanding, the policy implications of our theoretical argument and empirical findings are that a more differentiated perspective on the issue of environmental migration is urgently needed. It remains possible that abrupt and extreme climatic changes (or environmental changes more broadly) could force people to migrate permanently from some areas of the world, particularly from lowlying coastal areas in some developing countries. However, if the past provides any insights into what may happen in the future, our results suggest that depending on the type of environmental event people might prefer adaptation as a means to stay in their location over migration. This finding appears to apply especially to slow-onset, long-term environmental events. The main implication is, therefore, that improving the targeting of aid to environmental disaster-affected areas and the financial and technical support for adaptation to environmental change could be the most productive policyoptions. Consequently, policymakers need to implement a wide range of developmental policies in combination with environmental ones in order to improve society's ability to effectively cope with environmental change and minimize its effect on migration.

\section{NOTES}

1. We use the term "environmental migration" as relating to persons who are displaced primarily for environmental reasons (see Dun and Gemenne (2008) for a discussion on the definition of environmental migration).
2. Environmental migration has also been theorized to cause political conflict in the receiving areas (Bernauer, Böhmelt, \& Koubi, 2012; Buhaug, Gleditsch, \& Theisen, 2010; Gleditsch, Nordås, \& Salehyan, 2007; Raleigh, Jordan, \& Salehyan, 2008; Reuveny, 2007). 
3. For a much larger review of the existing literature, see: Hunter, Luna, and Norton (2015), McLeman (2014), Foresight: Migration and Global Environmental Change (2011).

4. Halliday (2006) and Robalino et al. (2015) are notable exceptions.

5. Air pollution and congestion are often mentioned as important factors affecting individuals' decision to reallocate from city centers to suburbs, and from metropolitan areas to small cities.

6. Similarly, Hunter (2005) and Bylander (2013) argue that perceptions of risk act as a "mediating factor" between environmental stress and migration.

7. As elaborated in the research design below, we do control for all of these alternative influences.

8. Renaud, Dun, Warner, and Bogardi (2011) propose a similar framework for environmentally induced migration, arguing that the type of the environmental event-rapid-onset vs. slow-onset-determines whether migration is forced or voluntary.

9. It is worth noting, that migration in the presence of short and sudden environmental events might not be permanent. Existing research shows that such environmental events lead overwhelmingly to short-term, internal displacements (Myers et al., 2008; Raleigh et al., 2008), and to metropolitan areas that are less dependent on agriculture or climate in general (Robalino et al., 2015). Individuals are usually tied to a particular location by lifestyle, bonds to other people, culture, social traditions, and identity. For these reasons, they are likely to return once conditions improve and rebuild their lives in a "familiar" setting (Raleigh et al., 2008). Unfortunately due to lack of temporal dimension of our survey, we are not able to establish whether migration is temporary or permanent.

10. Hunter et al. (2015, p. 13) identify environmental perceptions and their role on migration decisions as "the first empirical gap" in the existing literature.

11. The Environmental Change and Forced Migration (EACH-FOR) project was a research project within the Sixth Framework Programme of the European Commission. It constitutes the first global survey of environmental change and migration and investigated cases studies in 23 countries in six regions worldwide. The goal was to find out whether there was a "discernible environmental signal in migration patterns today" (Laczko \& Aghazarm, 2009, p. 204; see also Warner, 2011).

12. This sampling method is frequently used in sociological studies of such hidden populations (Laczko \& Aghazarm, 2009).

\section{REFERENCES}

Adamo, S., \& Izazola, H. (2010). Human migration and the environment. Population and Environment, 32, 105-108.

Adger, W. N., Agrawala, S., \& Mirza, M. Q. (2007). Assessment of adaptation, practices, options, constraints and capacity. In M. Parry (Ed.), Climate change 2007: Impacts, adaptation and vulnerability. Cambridge: IPCC/Cambridge University Press, Contribution of Working Group II to the Fourth Assessment Report of the Intergovernmental Panel on Climate Change.

Adger, W. N., Kelly, P. M., \& Ninh, N. H. (Eds.) (2001). Living with environmental change: Social vulnerability, adaptation and resilience in Vietnam. London: Routledge.

Berkes, F., \& Jolly, D. (2001). Adapting to climate change: Socialecological resilience in a Canadian western Arctic community. Conservation Ecology, 5(2), 18, [online] URL: http://www.consecol. org/vol5/iss2/art18.

Bernauer, T., Böhmelt, T., \& Koubi, V. (2012). Environmental changes and violent conflict. Environmental Research Letters, 7(1), 1-8.

Black, R., Adger, W. N., Arnell, N. W., Dercon, S., Geddes, A., \& Thomas, D. S. G. (2011). The effect of environmental change on human migration. Global Environmental Change, 21, S3-S11.

Buhaug, H., Gleditsch, N. P., \& Theisen, O. M. (2010). Implications of climate change for armed conflict. In R. Mearns, \& A. Norton (Eds.), Social dimensions of climate change: Equity and vulnerability. New frontiers of social policy (pp. 75-101). Washington, DC: World Bank.

Bylander, M. (2013). Depending on the sky: Environmental distress, migration, and coping in rural Cambodia. International Migration. http://dx.doi.org/10.1111/imig.12087.

Dasgupta, S., Laplante, B., Meisner, C., Wheeler, D., \& Yan, J. (2009). The impact of sea level rise on developing countries. A comparative analysis. Climatic Change, 93, 379-388.

de Menocal, P. B. (2001). Cultural responses to climate change during the late Holocene. Science, 292, 667-673.

Devine-Wright, P. (2013). Think global, act local? The relevance of place attachments and place identities in a climate changed world. Global Environmental Change, 23(1), 61-69.
Doevenspeck, M. (2011). The thin line between choice and flight: Environment and migration in rural Benin. International Migration, 49(S1), e50-e68.

Dun, O. (2011). Migration and displacement triggered by floods in the Mekong Delta, Vietnam. International Migration, 49(S1), e200-e223.

Dun, O., \& Gemenne, F. (2008). Defining environmental migration. Forced Migration Review, 31, 10-11.

EACH-FOR (Environmental Change and Forced Migration Scenarios). http://www.each-for.eu.

EM-DAT: The OFDA/CRED International Disaster Database. Université Catholique de Louvain, Brussels (Belgium), www.emdat.be.

Ford, J. D., Smit, B., \& Wandel, H. (2006). Vulnerability to climate change in the Arctic: A case study from Arctic Bay, Canada. Global Environmental Change, 16(1), 145-160.

Foresight Migration and Global Environmental Change (2011). Final project report. London: The Government Office for Science, http:// www.bis.gov.uk/foresight/migration.

Gemenne, F. (2011). Why the numbers don't add up: A review of estimates and predictions of people displaced by environmental changes. Global Environmental Change, 21, S41-S49.

General Statistics Office of Vietnam. (2013). Socio-economic situation in 2013. http://www.gso.gov.vn/default_en.aspx?tabid=622\&ItemID= 13848

Gleditsch, N. P., Nordås, R., \& Salehyan, I. (2007). Climate change and conflict: The migration link Coping with crisis working paper series. New York: International Peace Academy.

Gray, C. L. (2008). Environment, land and rural outmigration in the southern Ecuadorian Andes. World Development, 37(2), 457-468.

Gray, C., \& Mueller, V. (2012a). Natural disasters and population mobility in Bangladesh. Proceedings of the National Academy of Sciences, 109(16), 6000-6005.

Gray, C., \& Mueller, V. (2012b). Droughts and population mobility in rural Ethiopia. World Development, 40(1), 134-145.

Halliday, T. (2006). Migration, risk, and liquidity constraints in El Salvador. Economic Development and Cultural Change, 54(4), 893-925. 
Henry, S., Schoumaker, B., \& Beauchemin, C. (2004). The impact of rainfall on the first out- migration: A multi-level event-history analysis in Burkina Faso. Population \& Environment, 5(5), 423-460.

Hunter, L. M. (2005). Migration and environmental hazards. Population and Environment, 26(4), 273-302.

Hunter, L. M., Luna, J. K., \& Norton, R. M. (2015). Environmental dimensions of migration. Annual Review of Sociology, 41(6), 1-21.

ICEM (International Centre for Environmental Management). (2010). Climate change baseline assessment working paper. MRC Strategic Environmental Assessment (SEA) of Hydropower on the Mekong Mainstream, Vol. II. http://www.mrcmekong.org/assets/Publications/ Consultations/SEA-Hydropower/7-Climate-change-baseline-assessment.pdf.

IPCC Fifth Assessment Report (AR5). (2014a). Climate change 2014. Synthesis report. http://www.ipcc.ch/pdf/assessment-report/ar5/syr/ SYR_AR5_LONGERREPORT.pdf.

IPCC Fifth Assessment Report (AR5). (2014b). Climate change 2014. Impacts, adaptation, and vulnerability. Part B: Regional aspects Chapter 24: Asia, p. 1355. https://ipcc-wg2.gov/AR5/images/uploads/WGIIAR5-Chap24_FINAL.pdf.

Jäger, J., Frühmann, J., Grünberger, S., \& Vag, A. (2009). Environmental change and forced migration scenarios project synthesis report. Deliverable D.3.4 for the European Commission. http://www.eachfor.eu/documents/EACH-FOR_Synthesis_Report 090515.pdf.

King, G., Tomz, M., \& Wittenberg, J. (2000). Making the most of statistical analyses: Improving interpretation and presentation. American Journal of Political Science, 44, 341-355.

Kniveton, D., Schmidt-Verkerk, K., Smith, C., \& Black, R. (2008). Climate change and migration: Improving methodologies to estimate flows Migration research series no. 33. International Organization for Migration.

Laczko, F., \& Aghazarm, C. (Eds.) (2009). Migration, environment and climate change: Assessing the evidence. Geneva, $\mathrm{CH}$ : International Organization for Migration (IOM).

Lewicka, M. (2011). On the variety of people's relationship with places. Environment and Behavior, 43(5), 676-709.

Lonergan, S. (1998). The role of environmental degradation and population displacement. Environmental Change and Security Report, 4 $5-15$.

Massey, D. S. (1990). The social and economic origins of immigration. Annals of the American Academy of Political and Social Science, 510, $60-72$.

Massey, D. S., Arango, J., Hugo, G., Kouaouci, A., Pellegrino, A., \& Taylor, J. E. (1993). Theories of international migration: A review and appraisal. Population and Development Review, 19(3), 431-466.

Massey, D. S., Axinn, W., \& Ghimire, D. (2010). Environmental change and out-migration: Evidence from Nepal. Population and Environment 32(1), 109-136.

McLeman, R. A. (2014). Climate and human migration: Past experiences, future challenges. Cambridge University Press.

Mortreux, C., \& Barnett, J. (2009). Climate change, migration and adaptation in Funafuti, Tuvalu. Global Environmental Change, 19(1), $105-112$.
MRC (Mekong River Commission). (2009). Adaptation to climate change in the countries of the Lower Mekong Basin: Regional synthesis report. MRC technical paper no. 24. http://www.mrcmekong.org/assets/ Publications/technical/tech-No24-adaptation-to-climate- change.pdf.

Myers, N. (1997). Environmental refugees. Population \& Environment, 19 (2), 167-182

Myers, N. (2002). Environmental refugees: A growing phenomenon of the 21st century. Philosophical Transactions of the Royal Society, 357(1420) 609-613.

Myers, C. A., Slack, T., \& Singelmann, J. (2008). Social vulnerability and migration in the wake of disaster: The case of Hurricanes Katrina and Rita. Population \& Environment, 29(6), 271-291.

Nguyen, L. D., Raabe, K., \& Grote, U. (2015). Rural-urban migration, household vulnerability, and welfare in Vietnam. World Development, 71, 79-93.

Piguet, E. (2010). Linking climate change, environmental degradation, and migration: A methodological overview. Wiley Interdisciplinary Reviews: Climate Change, 1(4), 517-524.

Piguet, E., Pécoud, A., \& de Guchteneire, P. (2011). Migration and climate change. Cambridge University Press.

Raleigh, C. A. (2011). The search for safety: The effects of conflict, poverty and ecological influences on migration in the developing world. Global Environmental Change, 21, S82-S93.

Raleigh, C., Jordan, L., \& Salehyan, I. (2008). Assessing the impact of climate change on migration and conflict Paper prepared for the social dimensions of climate change. The World Bank.

Renaud, F. G., Dun, O., Warner, C., \& Bogardi, J. (2011). A decision framework for environmentally induced migration. International Migration, 49(1), e3-e29.

Reuveny, R. (2007). Climate change-induced migration and violent conflict. Political Geography, 26(6), 656-673.

Robalino, J., Jimenez, J., \& Chacon, A. (2015). The effect of hydrometeorological emergencies on internal migration. World Development, 67, 438-448.

Roncoli, C., Ingram, K., \& Kirshen, P. (2001). The costs and risks of coping with drought: Livelihood impacts and farmers' responses in Burkina Faso. Climate Research, 19, 119-132.

Speare, A. Jr., (1974). Residential satisfaction as an intervening variable in residential mobility. Demography, 11(2), 173-188.

Stark, O., \& Bloom, D. E. (1985). The new economics of labor migration. American Economic Review, 75(2), 173-178.

Suhrke, A. (1994). Environmental degradation and population flows. Journal of International Affairs, 47, 473-496.

Van der Geest, K. (2011). North-South migration in Ghana - What role for the environment. International Migration, 49(s1), e69-e94.

Warner, K. (2011). Environmental change and migration: Methodological considerations from ground-breaking global survey. Population \& Environment, 33(1), 3-27.

Warner, K., Afifi, T., Henry, K., Rawe, T., Smith, C., \& De Sherbinin, A. (2012). Where the rain falls: Climate change, food and livelihood security, and migration. Bonn: UNU and CARE.

Wolpert, J. (1966). Migration as an adjustment to environmental stress. Journal of Social Issues, 22(4), 92-102. 
APPENDIX

\section{Questionnaire}

Interview ID

Date:

$$
\text { I }
$$

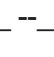

Location: [to be filled out prior to interview]

Coordinates:

Commune/Village/Town:

District:

Province:
Current Weather [observed]:

Number of households $(\mathrm{HH})$ in

village/town:

\section{Respondent: [based on observation]}

Household Status [scale determined before start of interview]

1. Very poor

2. Poor

3. Average

4. Above average

5. Wealthy

99. N/A [Circle if interview not conducted in respondent home]

Sex of Respondent

$\begin{array}{ll}\text { 1. Female 2. Male } & \end{array}$

\section{Interview Schedule}

How long have you lived in this location?

1. Since birth

2._ [years]

99. Don't Know/Refused to Answer

Where did you come from?

Commune/Village:

District

Province

Were you born there?

1. Yes

2. No

99. Don't Know/Refused to Answer

How long were you in that previous location for?

$$
\text { years }
$$

99. Don't Know/Refused to Answer 
What is the highest level of formal education you have attended? [Ask for specific number of years completed]

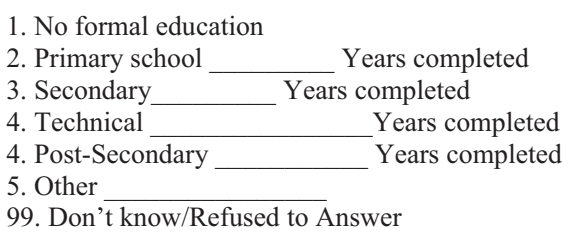

Could you tell us your age?

[If does not know or refuses to respond, interviewer to guess]

I will read you a list of sources of income. Could you tell us which is your (household) main source(s) of income? (Non-migrant) - I will read you a list of sources of income. Could you tell us which was your (household) main source(s) of income in your former location? (Migrant)

(Circle all mentioned. If more than one was mentioned, ask to rank them in order of importance (from 1-5, 1 the most important) (Insert number in spaces provided in question BELOW)

\begin{tabular}{|c|c|}
\hline 1. & Agriculture/Farm /animal /fishing income \\
\hline 2. & Proceeds as shop/business owner \\
\hline 3. & Proceeds markets sales (non-farm) \\
\hline 4. & Civil servant salary \\
\hline 5. & Salary from industry (firm, factory, corporation) \\
\hline 6. & Salary from labor (handicrafts, construction) \\
\hline 7. & Day Labor-Temporary \\
\hline 8. & Artisanal Mining \\
\hline 9. & Remittances \\
\hline 10. & Professional \\
\hline 11. & Other \\
\hline 99. & Don't Know /Refused to Answer \\
\hline
\end{tabular}

From your perspective, can you describe the main weather events that have happened here during the last 5 years? (Non-migrant) - From your perspective, Can you describe the main weather events that occurred during the past five years before you left your previous residence? (Migrant)

[If respondent is unable to answer freely, read the list. For each reported event follow up with questions in the following table]. [Circle all that apply] Show Card

1. Heavy Rains/Floods [please circle]

2. Salinity

3. Snow/Hail [please circle]

4. Drought/Desertification [please circle]

5. Storm/Cyclone/Typhoon [please circle]

6. Landslide/Mudslide/Avalanche [please circle $]$

7. Other

8. None

99. Don't Know/Refused to Answer 


\begin{tabular}{|c|c|c|c|c|c|c|c|}
\hline $\begin{array}{l}\text { Circle events } \\
\text { reported in } \\
\text { previous } \\
\text { question }\end{array}$ & $\begin{array}{l}\text { 1. Heavy } \\
\text { Rain/Flood }\end{array}$ & 2. Salinity & 3. Snow/Hail & $\begin{array}{l}\text { 4. Drought/ } \\
\text { Desertificatio } \\
\text { n }\end{array}$ & $\begin{array}{l}\text { 5. Cyclone/ } \\
\text { Typhoon/ } \\
\text { Storm }\end{array}$ & $\begin{array}{l}\text { 6. Landslide/ } \\
\text { Mudslide/ } \\
\text { Avalanche/ }\end{array}$ & 7. Other \\
\hline \multirow{3}{*}{$\begin{array}{l}\text { [For short } \\
\text { term events] } \\
\text { When did this } \\
\text { event last } \\
\text { occur? } \\
\text { [Or for } \\
\text { progressive } \\
\text { environmenta } \\
\text { levents] } \\
\text { When did } \\
\text { this event } \\
\text { begin? }\end{array}$} & & & & & & & \\
\hline & $\overline{\text { Month }}$ & $\overline{\text { Month }}$ & $\overline{\text { Month }}$ & $\overline{\text { Month }}$ & $\overline{\text { Month }}$ & Month & $\overline{\text { Month }}$ \\
\hline & $\begin{array}{l}\text { Year } \\
\text { 99. DK/RA }\end{array}$ & $\begin{array}{l}\text { Year } \\
\text { 99. DK/RA }\end{array}$ & $\begin{array}{l}\text { Year } \\
\text { 99. DK/RA }\end{array}$ & $\begin{array}{l}\text { Year } \\
\text { 99. DK/RA }\end{array}$ & $\begin{array}{l}\text { Year } \\
\text { 99. DK/RA }\end{array}$ & $\begin{array}{l}\text { Year } \\
\text { 99. DK/RA }\end{array}$ & $\begin{array}{l}\text { Year } \\
\text { 99. DK/RA }\end{array}$ \\
\hline $\begin{array}{l}\text { How long did } \\
\text { this event } \\
\text { last? }\end{array}$ & $\begin{array}{l}\text { 1. days } \\
\text { 2. weeks } \\
\text { 3. months } \\
\text { 4. years } \\
\text { 99. DK/RA }\end{array}$ & $\begin{array}{l}\text { 1. days } \\
\text { 2. weeks } \\
\text { 3. months } \\
\text { 4. years } \\
\text { 99. DK/RA }\end{array}$ & $\begin{array}{l}\text { 1. days } \\
\text { 2. weeks } \\
\text { 3. months } \\
\text { 4. years } \\
\text { 99. DK/RA }\end{array}$ & $\begin{array}{l}\text { 1. days } \\
\text { 2. weeks } \\
\text { 3. months } \\
\text { 4. years } \\
\text { 99. DK/RA }\end{array}$ & $\begin{array}{l}\text { 1. days } \\
\text { 2. weeks } \\
\text { 3. months } \\
\text { 4. years } \\
\text { 99. DK/RA }\end{array}$ & $\begin{array}{l}\text { 1. days } \\
\text { 2. weeks } \\
\text { 3. months } \\
\text { 4. years } \\
\text { 99. DK/RA }\end{array}$ & $\begin{array}{l}\text { 1. days } \\
\text { 2. weeks } \\
\text { 3. months } \\
\text { 4. years } \\
\text { 99. DK/RA }\end{array}$ \\
\hline
\end{tabular}

Have you ever thought about migrating? If yes, then ask: What was/were the reason(s)? (Nonmigrant) - I would like to ask you all the reason(s) why you decided to move from your former location. (Migrant)

[Allow respondents to answer without reading list and circle all responses in "Unprompted Column". Then follow up by reading list/Show Card. Additional responses should be circled in "Prompted Column"]

Social reasons: for example, Marriage; There are family/relatives in the new location; I was facing discrimination; There was insecurity (physical \&/or sexual); To seek health care (inadequate health care in area); To seek schooling (e.g. no school in area); Other

Economic reasons: for example, Not enough income from livelihood sources; Unreliable harvest; No land available for farming/agriculture; Crop failure; Unemployment in that location; Job opportunity in new place; Higher income in new place; Other

Environmental reasons: for example, Water shortage/Drought [1 event]; Repeated droughts /Long Term salinity; Too much water; Short term events such as flood, storm, landslide, cyclone: Single event or Repeated Event; Other

Political reasons: for example, There was conflict; To seek political freedom; Government provided incentives for me to go; Government forced me to move; Other

Of all the reasons you mentioned, could you please rank the top three most important factors?

[Write number of code from above reason in first, second and third place below, with number 1 as the most important]

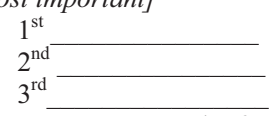

99. Don’t Know/Refused to Answer 
Up until now, have members of your household left temporarily or permanently for other places or even abroad? (Non-migrant) -Up until now, have other members of your household in your previous location left temporarily or permanently for other places, or even abroad? [Excluding respondent](Migrant)
1. Yes
2. No
99. Don't Know/Refused to Answer

Do you know of anyone who left after having experienced the same event(s) (drought/desertification/flood/cyclone/etc)? [Not from the same HH] (Non-migrant) - Do you know anyone else who left from your previous location around the same time you did? [Other than you] (Migrant)

1. Yes

2. No

99. Don’t Know/Refused to Answer

Where did they go? [List all locations mentioned]

Would you be willing to provide us with the name and contact information for these people so that we may ask a similar set of questions? 